\title{
Problems and solutions of water sector in Uzbekistan
}

\author{
Kurbanov Daniyar Rozumbayevich
}

\begin{abstract}
This article presents the main challenges of using water resources in Uzbekistan. Including:

- The problem of secondary use of water resources;

- The problem of developing an economic and financial mechanism for water use;

- The problem of rising prices for water use and water rent.

In order to solve the above problems the following are proposed:

- Create a legal and organizational-economic infrastructure adequate to the modern economic system of Uzbekistan;

- To carry out measures to rationalize water use in industry, agriculture and utilities, to reduce pollution of water bodies, to reduce damage from floods and other harmful effects of water.

- Carry out promising activities that ensure effective integrated use of water resources and their reproduction.
\end{abstract}

Keywords: improving water use efficiency, water rent, water tax, is the rationalization of water use, water resources.

\section{INTRODUCTION}

Water is an essential component of the environment, which is a limited, renewable and vulnerable natural resource. It also acts as an integral technological component of production processes in many sectors of the economy. Along with this, water resources are national wealth that is in the exclusive ownership of the state. The use of water resources should be carried out strictly on a legislative basis, involving the development of an appropriate economic and legal mechanism for their rational use and effective protection, that is, taking into account both economic and environmental, as well as legal aspects.

Indeed, one of the most urgent issues facing humanity today is the critical issue of water resource conservation, conservation, rational use and protection. Today, humanity has come to realize that it is not only the technology and the wonders of the universe that can be used to keep civilization on Earth, but also that the drinking water needed for life is sufficient.

It is estimated that over one-third of the world's population is in severe need of water resources in different regions. Drinking water is particularly scarce in Africa and Asia, and drought in some parts of the continent is causing severe drought and millions of people suffer from food shortages.

It is projected that by 2050 the world population will increase by 9 billion. As a result of global climate change, there may be various dangers and droughts in nature. Contemporary science recognizes that even if foodstuffs, non-renewable natural resources, and products created in other ways may be substituted in the future, water cannot

Revised Manuscript Received on 14, October 2019.

Kurbanov Daniyar Rozumbayevich, Independent researcher of the Banking and Finance Academy of Uzbekistan. replace them. Therefore, the depletion of potable water on the planet poses a serious threat. This is caused by the contamination of drinking water by groundwater, surface water from rivers and lakes by various chemical compounds.

In addition, about half of the world's rivers are polluted and their resources are depleted. Also, the area of marsh on the globe and inland water resources are shrinking. According to the data, every day 6,000 children die prematurely because of the consumption of water that does not meet hygiene standards.

At present the inland ponds, especially the rivers of Europe, are so polluted that they are unable to clean themselves naturally. Such water is not only suitable for consumption, but also for household, domestic and industrial needs.

The population growth in Uzbekistan and the reduction of water resources by $15-20 \%$ by 2020 is one of the challenges facing the country.

More than 2 trillion sums are allocated from the State budget annually for water supply of agricultural crops in Uzbekistan, and over 400 billion sums are allocated for improving the reclamation of irrigated lands. Result By the end of 2017, about 240,000 hectares of land were put into operation with low-cost technology. In particular, drip irrigation was implemented on 28,000 hectares.(1, Astana Conference).

Uzbekistan has the following problems with water resources use:

- The problem of secondary use of water resources;

- The problem of developing an economic and financial mechanism for water use;

- The problem of rising prices for water use and water rent.

The following study addresses these problems.

\section{RESEARCH METHODOLOGY}

The study used the experience of foreign countries in utilizing water resources and analyzed the current status of water resources use in Uzbekistan. The research methods used such methods as analysis, synthesis, induction, deduction.

\section{THE EXTENT TO WHICH THE SUBJECT IS STUDIED}

Economic Methods and Effective Use of Water Resources Bespalov N.F (2, Bespalov) , Bocharin A.V, Gaipnazarov N.A, Laktaev N.T, Yakubov H.E. (3, Bocharin and others) have been widely studied in his works. 
However, there is little research on the application of water rent and water taxes in the country. For this reason, this topic was explored by the author.

\section{ANALYSIS AND RESULTS}

The average long-term water resources of Uzbekistan's rivers are $11.5 \mathrm{~km} 3$ / year, or $18 \%$ of the total water demand. About $82 \%$ of the total water demand is covered by the Amudarya and Syrdarya resources. The maximum flow of these rivers is $123.08 \mathrm{~km} 3$. On the basis of this indicator, in accordance with the Interstate Agreement of the Aral Sea Basin, the limits of water consumption and the distribution of water between the countries of the region are established.

Table 1.

Approved water resources for Uzbekistan, km3

\begin{tabular}{|l|l|l|l|l|l|l|}
\hline River & $\begin{array}{l}\text { The head } \\
\text { of the river }\end{array}$ & $\begin{array}{l}\text { Little } \\
\text { rivers }\end{array}$ & Total & Groundwater & $\begin{array}{l}\text { Collector- } \\
\text { drain } \\
\text { streams }\end{array}$ & Total \\
\hline $\begin{array}{l}\text { The } \\
\text { Syrdarya }\end{array}$ & 10,49 & 9,2 & 19,69 & 1,59 & 4,21 & 25,49 \\
\hline $\begin{array}{l}\text { The } \\
\text { Amudarya }\end{array}$ & 26,92 & 6,98 & 33,9 & 1,00 & 2,63 & 37,53 \\
\hline Total *The table is formed by the authors & 37,4 & 16,18 & 53,59 & 2,59 & 6,84 & 63,02 \\
\hline
\end{tabular}

While the upper flow rate of $123,08 \mathrm{~km} 3$, which is considered to be a key indicator of transboundary water distribution, has retained its legal force, there are also other data available. In the context of seasonal management of the Amudarya river and long-term management of the Syrdarya river, the amount of water resources Uzbekistan may own (including $11.5 \mathrm{~km} 3$ of its rivers) is $63.02 \mathrm{~km} 3$. (4, Water A Vital Resource for Uzbekistan)

Due to these problems and limited water resources, Uzbekistan needs to introduce modern means of water management to the economy. Including:

\section{Secondary use of water resources}

Recycling of building effluents after appropriate treatment can successfully contribute to solving crisis situations existing in regions with insufficient water resources.

In many regions of our country there are serious problems with water supply due to insufficient water resources, and, as a result, water-saving technologies are becoming extremely important here.

Measures that could contribute to the conservation of natural resources and make a significant contribution to solving the problem, or at least relieve its severity, are as follows:

- stimulation of consumption reduction;

- water regeneration (if possible);

- reuse of effluents and rainwater (usually requires additional treatment).

In particular, the recycling of already used water reduces the level of pollution of natural massifs receiving waste water. The collection of rainwater in bathtubs or catchment tanks, followed by planned use, prevents overloading the sewer network in the event of heavy rainfall. In addition, if domestic and sewage drains into one sewer channel, this makes it possible not to liquefy sewage so much, because otherwise it would disrupt the biological phase of treatment. Regarding the secondary use of such water to protect public health, certain requirements have been established with regard to sanitary and hygienic and chemical parameters.
Depending on the desired quality of the final product, purification can be more or less complicated.

Development of the economic and financial mechanism for water use

The difference between a fixed payment to the budget (and a payment for the use of natural resources belongs to this category) and tax depends on the results of economic activity. Since the volume of used, especially 11 available or own resources does not depend on the results of current activities (and, of course, far from completely determines them), insofar as relations between the state and the nature user in this aspect are made out with a fixed payment. The tax reflects economic performance and is based on economic indicators determined by the market (prices), and for payments for mineral and water resources, rates must be set for all infinitely diverse deposits and water bodies. Precisely because such a task can only be solved very crudely, the desired redistribution of natural resource rent cannot be made by introducing payments alone: taxes on the results of economic activities (in principle, intended for other purposes) are also needed for the redistribution of natural rent, they dampen errors, unavoidable with "appointments" of financial indicators (but in fact, they perform broader functions even in the aspect under discussion). The payment for the used natural resources can be assigned in different ways, moreover, the various methods are compatible and can complement each other. As a rule, payment is charged for a useful natural substance (net) taken from the bowels, but sometimes all the extracted rock mass (gross) is taken into account. In a number of countries (for example, Australia), payments are practiced not only for used, but also for available but not exploited resources. The remaining variable details of the system of distribution and redistribution of natural rent, the mechanism of payment for environmental management are also found in various versions. In some countries, the state takes more from mining enterprises through taxes than through payments, in others - vice versa. One can see some (statistical) regularities: payments account for more where the budget and financial system is better tuned, a wealth of experience has been gained in paying for resource use, and, most importantly, the operating conditions for each specific resource are relatively uniform (in particular, there is less variety of deposits, respectively, less spread of payment rate values). Unfortunately, none of these characteristics is suitable for Uzbekistan.

Economic management methods are based on the collection of payments for the use of water resources and the discharge of pollutants, as well as on the introduction of an appropriate system of fines for violations of water use standards and incentives for their implementation, as well as for the implementation of measures to increase water use efficiency and reduce water consumption, reduce negative impact on water bodies, etc. 
In the Law "On Water and Water Use" (5, The Law Of The Republic Of Uzbekistan On Water And Water Use.) of the Republic of Uzbekistan, the charge for water use is proclaimed as the basic principle of economic regulation of the use, restoration and protection of water bodies. However, the introduction of a fee for water use and discharges of polluted effluents does not completely solve the problem of stimulating enterprises to introduce the best water-saving and water-treatment technologies, especially, the tasks of long-term development of water management.

Economic methods also include the establishment of tax and other benefits provided to enterprises in the implementation of low-waste technologies, the application of incentive measures and allowances for the production of environmentally friendly products and preferential lending to enterprises that effectively protect the environment. One of the mechanisms combining administrative and economic management methods is implemented through trust funds (budgetary or extra-budgetary). It is assumed that the funds from them, received in the form of fees for the use of water resources and for the negative impact on them (in particular, the discharge of pollutants), are used only to finance measures to reduce water consumption and sanitation, which are carried out both by private enterprises and state or municipal organizations.

The administrative mechanisms, without which it is impossible to ensure the normal development of market relations in the water sector, include:

- ensuring the liability of legal entities and individuals who, through their actions or inaction, caused the occurrence of a critical natural-economic situation;

- permission and licensing of activities related to water use and the harmful effects of water;

- establishment of limits for the use of water resources;

- environmental and economic expertise of water management projects and the organization of environmental education;

- improvement of legislation;

- Creation of environmental funds and control over their intended use. In addition, outside the region where market relations dominate, there remains a choice of measures implemented through budget financing. These include some hydroengineering structures that are unacceptable for commercial structures designed to protect against the harmful effects of water, water conservation measures and measures aimed at ensuring sanitary and hygienic safety. Moreover, the methods for implementing all such events after determining a budget customer can fully comply with market mechanisms.

The main difficulties in reforming the water management system of Uzbekistan are associated with limited financing opportunities for water management and water protection measures, low investment attractiveness of water management projects, limited privatization (as a rule, it can be economically effective only for water user sectors), the formation of natural monopolies in the use and distribution of water resources. The solution of the whole complex of problems requires dividing the totality of the measures taken into stages with the allocation of priority tasks.

Improving the system, management, it is advisable to carry out in three stages:
I stage. To create a legal and organizational-economic infrastructure adequate to the modern economic system of Uzbekistan; First of all, to reform the management system, and improve the organizational and economic mechanism. Introduce effective economic mechanisms, develop a regulatory framework, reverse the negative trends and stabilize the situation in the water sector, primarily for water supply to the population and the economy.

To solve the tasks of the first stage it is necessary:

development of the legislative and regulatory framework for the regulation of water use and land use in flood hazardous areas;

development of standards in accordance with the assessment of maximum permissible anthropogenic loads on water bodies.

II stage. To carry out measures to rationalize water use in industry, agriculture and utilities, to reduce pollution of water bodies, to reduce flood damage and other harmful effects of water. To solve the problems of the second stage, it is necessary to carry out:

transition to market relations in the water sector;

self-financing of the industry;

creation of a competitive environment for water use and sanitation;

introduction of a system of water management and environmental insurance;

restoration of biodiversity both in the object itself and in its floodplain;

development of economic and mathematical models for the rational use of water resources and their quality management with adaptation to specific objects.

III stage. Carry out promising activities that ensure effective integrated use of water resources and their reproduction. To solve the tasks of the third stage, it is necessary to carry out:

development of schemes for the integrated use and protection of water resources;

development of strategic plans for effective water resources management;

introduction of a payment for water use based on the extraction of the state of water rent;

water use pricing.

The implementation of all stages of improving water management implies mutual coordination of all federal and regional municipal governments, whose activities are related to solving the problems of developing the water management complex and managing water resources.

\section{CONCLUSION}

Summing up, I want to say that the study of the issue of water rent and the possibilities of its calculation leads to the conclusion that it is impossible at the moment to use a single integral indicator of the rental type, capable of ensuring the interaction of nature users and the environment. But, as it turns out, in practice in the financial and tax system a number of elements can successfully participate in the

Published By:

Blue Eyes Intelligence Engineering

\& Sciences Publication 
function of redistributing natural rents (and water rents in particular). Water taxes and fixed payments for the use of water resources, which are the basis of the economic mechanism for managing natural resources, are one of those elements whose main function is to rationalize water use. But when analyzing the issue of pricing in the water sector, we come to the conclusion that market forces are not able to ensure fair relations between environmental and economic agents without significant state support. That is, the water management system should be a harmonious synthesis of economic and 100 administrative methods designed to level out market failures, ensuring equal consideration of both environmental and economic requirements. (6, Danilov Danilyan).

An important aspect of the overall structure is the management of transboundary water bodies, based on the desire to achieve multilateral agreements based on trade in mutual benefits. For, as practice shows, in the case of coordinated actions, all interacting parties win both from an economic point of view and from a social, environmental, political position.

Improving the Uzbek management model is a long process, fraught with significant restructuring, transformation and significant financial costs. Therefore, it is time to move from a simple declaration and theoretical calculations to real actions that will allow Uzbekistan to embark on the path of sustainable development and integrated use of water resources.

\section{REFERENCES}

1. The experience of Uzbekistan in the rational use of water resources was highly appreciated at the Astana Conference http://xs.uz/uzkr/post/suv-resurslaridanoqilona-fojdalanish-bojicha-ozbekiston-tazhribasiostona-konferentsiyasida-yuqori-baholandi

2. Bespalov, N.F. (1992). etc. Reclamation and irrigation of crops of cotton crop rotation (hydro-modular zoning and irrigation regimes of agricultural crops in the regions of the Republic of Uzbekistan) Uzbek Academy of Agricultural Sciences. Tashkent-1992.

3. Bocharin, A.V., Gaipnazarov N.A., Laktaev N.T., Yakubov H.E. (2000) Handbook of hydraulic engineering of shirkats and Water Users Associations. Kituvchi, Tashkent -2000

4. WATER - A Vital Resource for Uzbekistan http://wash.earthforever.org/lib/uz/water_critical\%20reso urce_Uzbekistan_en_ru_uz/Uzbek/Water_uz_part_02[1]. pdf

5. THE LAW OF THE REPUBLIC OF UZBEKISTAN ON WATER AND WATER USE. No. 837-XII 05/06/1993. http://lex.uz/docs/93202

6. Danilov - Danilyan, V.I. Rationale for water management strategies. - M.: Scientific World, 2006 $336 \mathrm{p}$. 